\title{
Removal of uranium(VI) from aqueous solutions using Eucalyptus citriodora distillation sludge
}

\author{
H. N. Bhatti $\cdot$ S. Hamid
}

Received: 23 July 2012/Revised: 3 January 2013/Accepted: 10 March 2013/Published online: 17 May 2013

(C) Islamic Azad University (IAU) 2013

\begin{abstract}
Adsorption and desorption of uranium(VI) from dilute aqueous solutions by Eucalyptus citriodora distillation sludge was studied in a batch mode. The potential of Eucalyptus citriodora distillation sludge to remove uranium(VI) from aqueous solutions has been investigated at different conditions of solution $\mathrm{pH}$, metal ion concentrations, biosorbent dosage, biosorbent particle size, contact time and temperature. The results indicated that biosorption capacity of Eucalyptus citriodora distillation sludge was strongly affected by the medium $\mathrm{pH}$, the biosorbent dose, metal ion concentrations and medium temperature. Reduction in particle size increased the biosorption capacity. Langmuir and Freundlich isotherm models were applied to biosorption data to determine the biosorption characteristics. An optimum biosorption capacity $(57.75 \mathrm{mg} / \mathrm{g})$ was achieved with $\mathrm{pH} 4.0$, particle size $0.255 \mathrm{~mm}$, biosorbent dose $0.5 \mathrm{~g} / 100 \mathrm{~mL}$ and initial uranium(VI) concentration of $100 \mathrm{mg} / \mathrm{L}$. Uranium(VI) removal by Eucalyptus citriodora distillation sludge was rapid, the equilibrium was established within $60 \mathrm{~min}$ and pseudo-second-order model was found to fit with the experimental data. The biosorption process decreased with an increase in the temperature indicating its exothermic nature. Pretreatments of biomass with different reagents affected its biosorption capacity. A significant increase $(34 \%)$ in biosorption capacity $(83.25 \mathrm{mg} / \mathrm{g})$ was observed with benzene treatment. Fourier-transform infra-red studies showed the involvement of carbonyl, carboxyl and amide groups in the biosorption process. The results indicated that
\end{abstract}

H. N. Bhatti $(\bowtie) \cdot$ S. Hamid

Environmental Chemistry Laboratory, Department of Chemistry and Biochemistry, University of Agriculture,

Faisalabad, Pakistan

e-mail: hnbhatti2005@yahoo.com sulfuric acid had the best effects as an eluent showing $93.24 \%$ desorption capacity.

Keywords Uranium · Eucalyptus biomass - Biosorption · Recovery $\cdot$ Pretreatments

\section{Introduction}

Uranium is one of the important heavy metals possessing radioactivity and chemical toxicity. Among the naturally occurring actinides, uranium is most abundant radiotoxic heavy metal having average concentration of $1.7 \mathrm{mg} / \mathrm{kg}$ and exists in the form of three different radioisotopes ${ }^{238} \mathrm{U}$ $\left(99.27 \%, \quad t_{1 / 2}=4.51 \times 10^{9}\right), \quad{ }^{235} \mathrm{U} \quad\left(0.720 \%, \quad t_{1 / 2}=\right.$ $\left.7.13 \times 10^{8}\right)$ and ${ }^{234} \mathrm{U}\left(0.0055 \%, \quad t_{1 / 2}=2.48 \times 10^{5}\right)$ (Jovanovic et al. 2012; Li et al. 2012). Uranium naturally shows various oxidation states $(2+, 3+, 4+, 5+$ and $6+)$, but mostly found in its hexavalent form, $\mathrm{U}(\mathrm{VI})$. Usually in nature, uranium is associated with oxygen, forming the uranyl ion $\left(\mathrm{UO}_{2}{ }^{2+}\right)$. In strongly reducing conditions like water saturated with organic matter, uranium is often found in tetravalent state (Zou and Zhao 2012). It forms more than 160 mineral species and accounts for $5 \%$ of all known mineral (Kalin et al. 2005).

Uranium is used extensively in different industrial processes and in nuclear industry especially due to its wide applications. Excessive amounts of wastewater containing uranium are produced by the nuclear industry, ore mining and industries that utilize radioisotopes. Uranium released into the environment through various activities can reach the food chain and be ingested by human. Major uranium toxic effects are caused by its chemical toxicity and can accumulate in different body parts, resulting in blood and kidney problem and increase risk of bone and liver cancer 
(Xie et al. 2008). The United States Environment Protection Agency (US-EPA) has set the maximum acceptable level of $30 \mu \mathrm{g} / \mathrm{L}$ and World Health Organization (WHO) strictly recommended a $2 \mu \mathrm{g} / \mathrm{L}$ as the maximum contaminant level (MCL) for uranium (Saifuddin and Dinara 2012). Therefore, the need for economic and effective methods for the removal of uranium and other toxic pollutants from the environment resulted in the development of new separation techniques (Gok and Aytas 2009).

Conventional treatment techniques such as ionexchange, reverse osmosis, precipitation, flocculation, electrochemical treatment, solvent extraction, adsorption on activated carbon and membrane-related processes are usually applied for the remediation of heavy metals. These techniques are often expensive and inefficient, complicated and have production of toxic chemical sludge and its disposal problems (Dursun 2006; Boota et al. 2009; Bhatti et al. 2010). Hence, it is necessary to find suitable alternative technologies which are affordable, efficient and can compliment or replace the existing methods. Biosorption of metals is one of the possible innovative techniques involved in the remediation of heavy metals and radionuclides from wastewaters and subsurface environment (Tuzen et al. 2008; Bhatti et al. 2009). Biosorption involves the accumulation of heavy metals ions by biological materials either by metabolically mediated methods or by purely physico-chemical means. Like the conventional treatment methods biosorption also suffers with the disposal problem of sludge biomass. However, this technique has high efficiency and selectivity for absorbing heavy metals in low concentrations, cheap in nature, energysaving, broad operational range of $\mathrm{pH}$ and temperature, easy reclamation of heavy metal, easy recycling of the biosorbent, economical nature and eco-friendly behavior (Kratochvil and Volesky 1998; Boddu et al. 2003).

During the last few years some studies have been carried out for the removal of uranium from aqueous systems using various biomaterials. Some low-cost biosorbents such as sargassum biomass (Yang and Volesky 1999), water hyacinth (Bhainsa and D'Souza 2001), algal biomass (Kalin et al. 2005), banyan leaves, red algae (Bhat et al. 2008), alginate beads (Gok and Aytas 2009), Aspergillus fumigatus (Wang et al. 2010), citrus biomass (Saleem and Bhatti 2011), pine saw dust (Zou and Zhao 2012), etc. have been exploited for various workers. However, these low-cost biosorbents have generally low adsorption capacity and require large amounts of adsorbents. Since agricultural waste biomasses are available in abundance and cheap materials, it is necessary to continue searching for the most promising adsorbents.

Eucalyptus citriodora is an evergreen plant and its leaves yield a lemon-scented oil rich in citronellal, used in perfumery. Biomass left after the extraction of essential oils is a waste material having no commercial significance. Natural occurrence of this biomass makes this biomass a cheap source as biosorbent material having high-specific surface area $\left(4.56 \mathrm{~m}^{2} / \mathrm{g}\right.$ as determined by nitrogen adsorption BET method). Therefore, the goals of this research work were to explore the feasibility for removal of uranium by Eucalyptus citriodora distillation sludge (ECDS), investigate the biosorption capacity of ECDS and analyze the surface interactions between ECDS and U(VI).

\section{Materials and methods}

Chemicals and biomass

All the chemicals used in the present study were of analytical reagent (RA) grade including uranyl nitrate hexahydrate $\left[\mathrm{UO}_{2}\left(\mathrm{NO}_{3}\right)_{2} \cdot 6 \mathrm{H}_{2} \mathrm{O}\right]$, Arsenazo III, diethylenetriaminepenta acetic acid (DTPA) which were mainly obtained from Sigma Chemical Co, USA. A solution of $1,000 \mathrm{mg} / \mathrm{L}$ of uranium was prepared from $\mathrm{UO}_{2}\left(\mathrm{NO}_{3}\right)_{2} \cdot 6 \mathrm{H}_{2} \mathrm{O}$ by dissolving the salt in deionized distilled water (DDW). ECDS used in this work was collected from Rose Laboratory, Institute of Horticultural Sciences, University of Agriculture Faisalabad, Pakistan. It was extensively washed with distilled water to remove particulate material from their surface then dried first in sun then in oven at $60-70{ }^{\circ} \mathrm{C}$. Dried biomass was ground and sieved to obtain the different sizes of biosorbent.

\section{Biosorption experiments}

All glassware were washed with dilute solution nitric acid $\left(\mathrm{HNO}_{3}\right)$ and subsequently rinsed with DDW to remove any possible interference. Batch biosorption studies were carried out in $250-\mathrm{mL}$ conical flasks to observe the effect of $\mathrm{pH}(2-8)$, biosorbent particle size $(0.255-0.71 \mathrm{~mm})$, biomass dosage $(0.1-0.7 \mathrm{~g} / 100 \mathrm{~mL})$, initial uranium concentration $(25-300 \mathrm{mg} / \mathrm{L})$, contact time $(5-240 \mathrm{~min})$ and temperature $\left(30-50{ }^{\circ} \mathrm{C}\right)$ to check the optimal removal of the $\mathrm{U}(\mathrm{VI})$. The $\mathrm{pH}$ of the solution medium was adjusted with $0.1 \mathrm{M}$ solutions of sodium carbonate $\left(\mathrm{Na}_{2} \mathrm{CO}_{3}\right)$ and $\mathrm{HNO}_{3}$. Control assays were also run with each experiment. The conical flasks were agitated at $100 \mathrm{rpm}$ speed in a rotating shaker for a specified time period. At the end of the experiments, the conical flasks were removed from the shaker and the solutions were centrifuged at 5,000 rpm for 15 min to separate the biomass from the solution. The supernatant was used for $\mathrm{U}(\mathrm{VI})$ analysis.

Uranium analysis

$\mathrm{U}(\mathrm{VI})$ analysis was carried out using colorimetric method (Bhatti et al. 1991) Appropriate amount $(0.5 \mathrm{~mL})$ of the 
sample solution was pipetted out into a $25-\mathrm{mL}$ volumetric flask, $1 \mathrm{~mL}$ of complexing solution (2.5\% DTPA) and $0.5 \mathrm{~mL}$ Arsenazo-III reagent solution were added. The volume was made up with DDW ( $\mathrm{pH} 2.0$ ) and the solution was allowed to stand for 2-3 min. The pink-violet coloration that developed due to the formation of uranium-Arsenazo-III complex was measured at $655 \mathrm{~nm}$ against a corresponding reagent blank, using a $1-\mathrm{cm}$ path cell in an Optima sp-300 spectrophotometer.

\section{Biomass pretreatments}

ECDS biomass was physically modified using heating and boiling ( $5 \mathrm{~g}$ of biosorbent/100 $\mathrm{mL}$ of $\mathrm{H}_{2} \mathrm{O}$, heated or boiled for $10 \mathrm{~min}$ ). In case of chemical pretreatments $5 \mathrm{~g}$ of the biomass was soaked with $100 \mathrm{ml}$ of $5 \%$ solutions of sodium hydroxide, acetic acid, ammonium sulfate, acetone, nitric acid, ethylenediamminetetraacetic acid disodium salt (EDTA), hydrochloric acid, sulfuric acid, ethanol, methanol, benzene, glutaraldehyde, poly(ethyleneimine) (PEI) and ammonium chloride. These flasks containing chemically treated ECDS biomass were agitated for $30 \mathrm{~min}$ at $100 \mathrm{rpm}$ and $30^{\circ} \mathrm{C}$. All the pretreated samples were allowed to stand for a night at room temperature. The treated biomasses were extensively washed with DDW and filtered thoroughly. After filtration the residues were dried at $60{ }^{\circ} \mathrm{C}$ for $24 \mathrm{~h}$ and then the dried biomasses were used in adsorption experiments under optimum conditions (Bhatti et al. 2009).

\section{Desorption studies}

Different eluting reagents like EDTA, ammonium sulfate, hydrochloric acid, sulfuric acid, ammonium chloride, nitric acid, sodium hydroxide and acetic acid were tried to desorb the adsorbed uranium ions. Consecutive batch adsorption and desorption experiments were performed to test the ability of ECDS to be reutilized after regeneration. Before the desorption experiments, the adsorption experiments were carried out under optimum conditions and the ECDS biomass of adsorption experiments was dried at $60{ }^{\circ} \mathrm{C}$ for $24 \mathrm{~h}$, then optimum dose of this uranium loaded biomass was added in $250-\mathrm{ml}$ flasks containing $100 \mathrm{ml}$ of $0.1 \mathrm{M}$ of each eluent. The eluent which showed the maximum desorption efficiency was selected for final recovery of uranium ions using various concentration $(0.05,0.1,0.15$, 0.2 and $0.25 \mathrm{M})$. After optimizing the strength of the selected eluent the consecutive adsorption-desorption cycles were carried out five times.

The amount of U(VI) adsorbed per unit mass of ECDS, percentage adsorption and the distribution constant $\left(K_{\mathrm{d}}\right)$ were calculated using the following equations:
$q_{\mathrm{e}}=\left(C_{\mathrm{i}}-C_{\mathrm{e}}\right) V / W$

$\%$ adsorption $=\left(C_{\mathrm{i}}-C_{\mathrm{e}}\right) 100 / C_{\mathrm{i}}$

$K_{\mathrm{d}}=\frac{\text { Amount of metal ion in adsorbent }}{\text { Amount of metal ions in solution }}$

$q_{\mathrm{e}}$ is the biosorption capacity $(\mathrm{mg} / \mathrm{g})$ under equilibrium conditions, $V$ is volume of aqueous phase $(\mathrm{mL}), C_{\mathrm{i}}$ is initial metal ion concentration $(\mathrm{mg} / \mathrm{L}), C_{\mathrm{e}}$ is equilibrium metal ion concentration and $W$ is the amount of biosorbent $(\mathrm{g})$.

The eluted biomass metal contents were calculated directly from the amount of metal desorbed into the eluent solution by using the following equation.

$q_{\mathrm{des}}=C_{\mathrm{des}} V / W$

$q_{\text {des }}$ is desorption capacity $(\mathrm{mg} / \mathrm{g})$ and $C_{\text {des }}$ is metal concentration in eluent solution or desorbed concentration of metal ion $(\mathrm{mg} / \mathrm{L})$

The percentage of desorbed/eluted metal is evaluated as $\%$ elution

$\%$ elution $=\left[q_{\mathrm{des}} / q_{\mathrm{e}}\right] \times 100$

Thermodynamics of uranium adsorption

The thermodynamic parameters such as standard Gibbs free energy $\left(\Delta G^{0}\right)$, standard enthalpy change $\left(\Delta H^{0}\right)$ and standard entropy of adsorption $\left(\Delta S^{0}\right)$ were calculated from the following equation:

$\Delta G^{0}=-R T \ln K_{\mathrm{c}}$

where $K_{\mathrm{c}}=\left(q_{\mathrm{e}} / C_{\mathrm{e}}\right)$

$R$ is the gas constant $(8.314 \mathrm{~J} / \mathrm{mol} \mathrm{K}), T$ is the absolute temperature $(\mathrm{K})$ and $K_{\mathrm{c}}$ is the equilibrium constant.

According to van't Hoff equation

$\Delta G^{0}=\Delta H^{0}-T \Delta S^{0}$

$\log \left(q_{\mathrm{e}} / C_{\mathrm{e}}\right)=-\Delta G^{0} / 2.303 R T$

$$
=-\Delta H^{0} / 2.303 R T+\Delta S^{0} / 2.303 R
$$

The values of $\Delta G^{0}$ and $\Delta H^{0}$ for $\mathrm{U}(\mathrm{VI})$ biosorption were determined from the slope and intercept of van't Hoff graph.

\section{FTIR and EDX studies}

The functional groups of ECDS biomass were analyzed by Bruker Tensor 27 Fourier transform infrared (FTIR) spectrometer with the samples prepared as potassium bromide $(\mathrm{KBr})$ disks. The existence of uranium ions on the surface of biomass was confirmed by energy dispersive X-ray spectroscopy (EDX, Perkin-Elmer, USA). The biomass sample was covered with a thin layer of gold and an electron-accelerated voltage of $20 \mathrm{kV}$ was applied. 
Statistical analysis

All the experiments were run in triplicate and results are reported as mean $\pm \mathrm{SD}$. The error bars have been shown on the graphs.

\section{Results and discussion}

\section{Effect of medium $\mathrm{pH}$}

Aqueous solution $\mathrm{pH}$ is a critical parameter as it affects surface charge of the biosorbent, the degree of ionization and the speciation of adsorbate species, and concentration of the counter ions on the functional groups of the biosorbent. The solution chemistry of the heavy metals such as hydrolysis, complexation by organic or inorganic ligands, redox reactions and precipitation are also strongly influenced by $\mathrm{pH}$ (Ozer and Ozer 2003). Uranium sorption by ECDS was studied in the $\mathrm{pH}$ region between 2.0 and 8.0 and the results regarding biosorption capacity $(\mathrm{mg} / \mathrm{g})$ and $K_{\mathrm{d}}$ are shown in Fig. 1. As seen from the figure, the biosorption capacity $q_{\mathrm{e}}$ of biomass and $K_{\mathrm{d}}$ increase with an increase in $\mathrm{pH}$ of the medium from 2.0 to 4.0 , and then show a decrease at 5.0. Extremely acidic conditions $\mathrm{pH}$ 2.0) did not favor uranium biosorption. Maximum uptake $(47.75 \mathrm{mg} / \mathrm{g})$ was attained at $\mathrm{pH} 4.0$, with a further rise in $\mathrm{pH}$, uranium biosorption by ECDS showed a sharp decline. Under acidic conditions there is high concentration of $\mathrm{H}^{+}$ and $\mathrm{H}_{3} \mathrm{O}^{+}$ions which compete with the uranyl ions for binding sites on the surface of biomass, resulting in a decreased biosorption of uranium (Sar and D' Souza 2002). Decrease in the biosorption capacity of ECDS and $K_{\mathrm{d}}$ for uranium ion at higher $\mathrm{pH}$ could be due to the formation of uranyl complexes such as, $\mathrm{UO}_{2} \mathrm{OH}^{+},\left(\mathrm{UO}_{2}\right)_{2}(\mathrm{OH})_{2}^{2+}$ and $\left(\mathrm{UO}_{2}\right)_{3}(\mathrm{OH})_{5}^{+}$. These complexes may compete with functional binding sites for uranyl ions and reduce the availability of uranium for biosorption and hence $K_{d}$ (Wazne et al. 2006). Gok and Aytas (2009) also observed maximum biosorption of uranium (76 \%) by calcium alginate

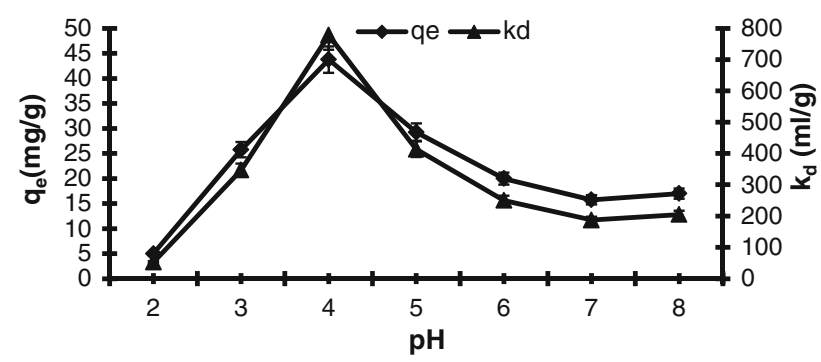

Fig. 1 Effect of $\mathrm{pH}$ on the adsorption of U(VI) by ECDS (dose $0.5 \mathrm{mg} / 100 \mathrm{~mL}$; concentration $100 \mathrm{mg} / \mathrm{L}$, time $45 \mathrm{~min}$; size $0.255 \mathrm{~mm}$; temperature $30{ }^{\circ} \mathrm{C}$ ) beads from aqueous solution at $\mathrm{pH}$ 4.0. Therefore, an optimum $\mathrm{pH} 4.0$ was selected in all subsequent experiments.

\section{Effect of biosorbent size}

The biomass particle size determines the surface area of the biosorbent. The effect of altering the biosorbent particle size on the biosorption capacity $q_{\mathrm{e}}$ of ECDS and $K_{\mathrm{d}}$ was investigated and the trends are illustrated in Fig. 2. The results indicated that biosorption capacity and $K_{d}$ decreased with an increase in particle size of ECDS. Maximum biosorption capacity $(47.82 \mathrm{mg} / \mathrm{g})$ and $K_{\mathrm{d}}$ value were observed with $0.255 \mathrm{~mm}$ particle size while largest particle size $(0.71 \mathrm{~mm})$ exhibited less adsorption for uranium ions as well as $K_{\mathrm{d}}$. This was most probably due to increase in total surface area, which provided more adsorption sites for the metal ions. The finely grounded biomass up took the metal ions more rapidly and the equilibrium was established faster than those achieved with large particle-sized biomass. These observations are in accord with our previous results in which adsorption capacity of biomass decreased with an increase in the size of adsorbents (Bhatti et al. 2009, 2010).

\section{Effect of biosorbent dose}

The dependence of U(VI) biosorption on biosorbent dose was studied by varying the amount of biosorbent while keeping $\mathrm{pH}(4)$, biosorbent particle size $(0.255 \mathrm{~mm})$, initial uranium ion concentration $(100 \mathrm{mg} / \mathrm{L})$, shaking speed $(100 \mathrm{rpm})$ and temperature $\left(30^{\circ} \mathrm{C}\right)$ constant. Biosorbent dose seems to have a great influence on the biosorption process. Results revealed that maximum biosorption capacity $(57.75 \mathrm{mg} / \mathrm{g})$ and $K_{\mathrm{d}}$ were observed with $0.5 \mathrm{~g} /$ $100 \mathrm{~mL}$ of U(VI) solution (Fig. 3). The results showed that biosorption capacity of ECDS and $K_{\mathrm{d}}$ increased with

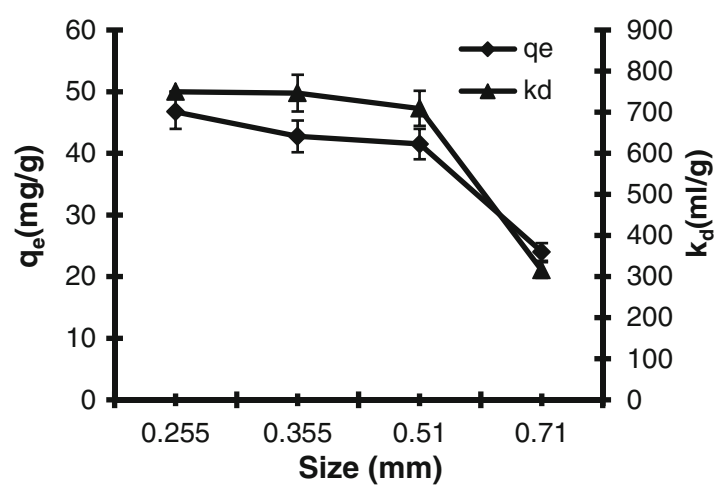

Fig. 2 Effect of adsorbent size on the adsorption of U(VI) by ECDS (dose $0.5 \mathrm{mg} / 100 \mathrm{~mL}$; concentration $100 \mathrm{mg} / \mathrm{L}$, time $45 \mathrm{~min}$; $\mathrm{pH} \mathrm{4}$; temperature $30{ }^{\circ} \mathrm{C}$ ) 


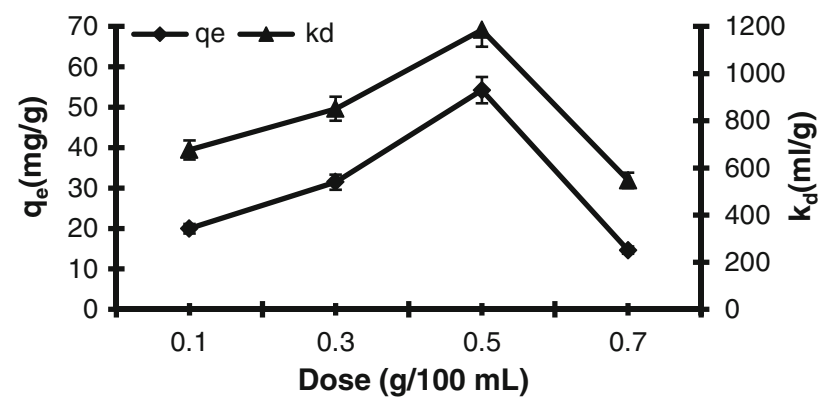

Fig. 3 Effect of adsorbent dose on the removal of U(VI) ECDS (time $45 \mathrm{~min}$; concentration $100 \mathrm{mg} / \mathrm{L}$, size $0.255 \mathrm{~mm}$; $\mathrm{pH} \mathrm{4}$; temperature $30{ }^{\circ} \mathrm{C}$ )

increase in biosorbent dose. The increase is due to increased surface area of the biosorbent, which in turn increases the number of binding sites. But the biosorption capacity $q_{\mathrm{e}}$ and $K_{\mathrm{d}}$ decreased when the biosorbent dose is increased above the optimum value. The decrease is due to partial aggregation and screening effect on the biomass surface which occurred at high biomass dose (Boota et al. 2009). Such aggregation would lead to a decrease in total surface area of the sorbent and increase in diffusional path length. The aggregation of the biosorbent depends on the size of the particle. The smaller the size, greater would be the chances of aggregation. Similarly biosorption of U(VI) by immobilized Aspergillus fumigatus beads decreased from 7.2 to $1.7 \mathrm{mg} / \mathrm{g}$ when the adsorbent dose is increased from 1 to $3.5 \%$ (Wang et al. 2010).

\section{Effect of contact time}

The equilibrium time is one of the important parameters for an economical wastewater treatment system. The effect of contact time on the biosorption of uranium by ESDS was studied over time intervals from 5 up to 240 min. Figure 4 shows the amount of uranium biosorbed as a function of contact time. As seen from the

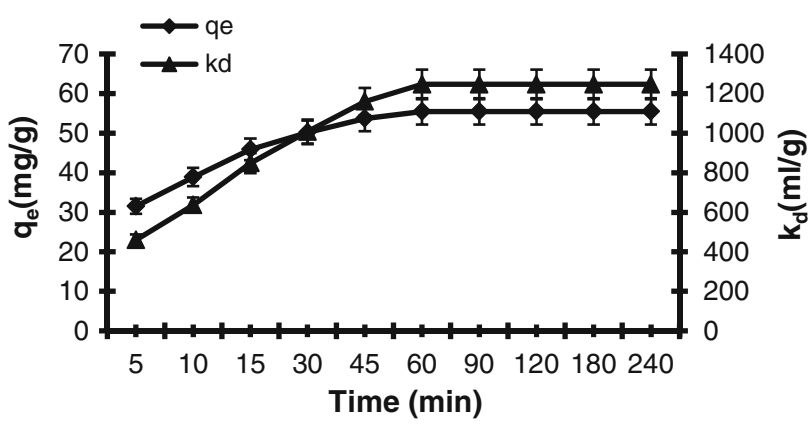

Fig. 4 Effect of time on the removal of U(VI) by ECDS (dose $0.5 \mathrm{~g}$ / $100 \mathrm{~mL}$; concentration $100 \mathrm{mg} / \mathrm{L}$, size $0.255 \mathrm{~mm}$; $\mathrm{pH}$ 4; temperature $30{ }^{\circ} \mathrm{C}$; contact time $5-240 \mathrm{~min}$ ) plot, the biosorption rate was rapid in the first $30 \mathrm{~min}$, reaching about $90 \%$ of the total biosorption capacity. Same trend was also recorded for the $K_{\mathrm{d}}$. Equilibrium was established within $60 \mathrm{~min}$. A biosorption capacity of $57.75 \mathrm{mg} / \mathrm{g}$ was observed under optimal conditions of $\mathrm{pH}$ (4.0), biosorbent dosage $(0.5 \mathrm{~g} / 100 \mathrm{~mL})$, biosorbent particle size $(0.255 \mathrm{~mm})$, initial metal ion concentration $(100 \mathrm{mg} / \mathrm{L})$, shaking speed $(100 \mathrm{rpm})$ and temperature $30{ }^{\circ} \mathrm{C}$. Therefore, in subsequent experiments, $90 \mathrm{~min}$ was deemed more than sufficient to establish equilibrium and used in all subsequent measurements. Gok and Aytas (2009) reported that equilibrium was reached after $90 \mathrm{~min}$ during biosorption of $\mathrm{U}(\mathrm{VI})$ from aqueous solution using calcium alginate beads.

\section{Effect of initial uranium concentration}

The rate of biosorption is a function of the initial metal ion concentration, which makes it an important factor to consider for effective biosorption. The initial concentration of uranium provides an important driving force to overcome all mass transfer resistance of uranium between the aqueous and solid phases. The biosorption capacity of ECDS for uranium was determined at different concentrations $(25-300 \mathrm{mg} / \mathrm{L})$. It was observed that the biosorption capacity of ECDS and $K_{\mathrm{d}}$ both increased with an increase in the uranium ion concentration. The maximum $K_{\mathrm{d}}$ and uptake capacity of ECDS $(57.86 \mathrm{mg} / \mathrm{g})$ were observed with the initial uranium concentration of $100 \mathrm{mg} / \mathrm{L}$ (Fig. 5), but $K_{\mathrm{d}}$ later decreased. This might be due to the saturation of the adsorption sites and increase in the number of ions competing for the available binding sites in the adsorbent for complexation of uranium at higher concentration (Bai and Abraham 2003). Moreover, the increase in uranium concentration enhanced the mass transfer driving force which enhanced the biosorption process at equilibrium (Aksu 2002; Zubair et al. 2008). In addition, increasing metal ion concentrations increased the number of collision

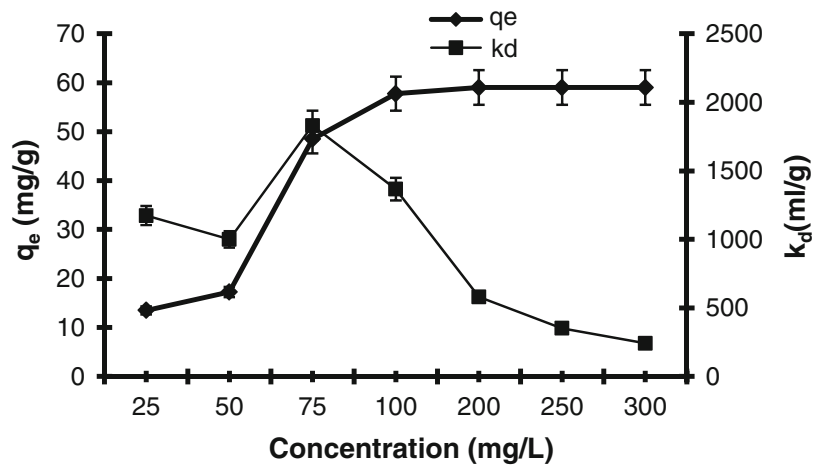

Fig. 5 Effect of concentration on the removal of U(VI) by ECDS (dose $0.5 \mathrm{~g} / 100 \mathrm{~mL}$; temperature $30{ }^{\circ} \mathrm{C}$, size $0.255 \mathrm{~mm}$; time $60 \mathrm{~min}$; $\mathrm{pH} 4)$ 
between metal ions and the adsorbent, which enhanced the biosorption process (Aksu 2002).

Equilibrium isotherm and kinetic studies

Modeling of equilibrium data was done using most widely used Langmuir (1918) and Freundlich isotherm (1906) models. The monolayer coverage of the sorbate on a sorbent surface at constant temperature is represented by Langmuir isotherm, the biosorption of solute from aqueous solution onto the biosorbent surface is occurred as monolayer biosorption on the homogeneous number of exchanging sites. The Langmuir isotherm considers sorption as a chemical phenomenon. In the Langmuir model, maximum monolayer adsorption capacity, $q_{\max }(\mathrm{mg} / \mathrm{g})$, and other parameters were determined from following equation:

$\frac{C \mathrm{e}}{q \mathrm{e}}=\frac{1}{q \operatorname{Max} K_{\mathrm{L}}}+\frac{C \mathrm{e}}{q \mathrm{Max}}$

where $q_{\mathrm{e}}$ is the biosorption capacity at equilibrium $(\mathrm{mg} / \mathrm{g})$, $C_{\mathrm{e}}$ the equilibrium concentration of metal ion solutions, $q_{\text {max }}$ represents the maximum biosorption capacity and $K_{\mathrm{L}}$ is the Langmuir biosorption constant representing the ratio of biosorption/desorption rates.

The biosorption capacity $q_{\mathrm{e}}(\mathrm{mg} / \mathrm{g})$ of ECDS for uranium ions was determined by following equation of Freundlich isotherm:

$\log q \mathrm{e}=\frac{1}{n} \log C \mathrm{e}+\log k$

$k$ and $n$ are constants for Freundlich equation; where $k$ is a measure of adsorption capacity and $1 / n$ the intensity of adsorption. In the present investigation, Freundlich transformation was found to be linear and value of $q_{\max }$ as calculated from Freundlich model was in good agreement with that of the experimental value (Table 1). The good fit to the Freundlich adsorption isotherm model suggests multilayer sorption of U(VI) on ECDS and biosorption mechanism is through physical forces.

In order to understand the rate limiting step of U(VI) biosorption on ECDS, Lagergren pseudo-first-order (Lagergren 1898) and pseudo-second-order models were applied to describe the kinetic characteristics of the biosorption process. Pseudo-first-order kinetic model is based on the fact that the change in adsorbate concentration with respect to time is proportional to the number of binding sites on the adsorbent. The linearlized first-order Lagergren equation is given as:

$\log \left(q_{\mathrm{e}}-q\right)=\log q_{\mathrm{e}}-\frac{k_{1, a d s} t}{2.303}$

According to pseudo-second-order model the change in the adsorbate concentration with respect to time is proportional to square of binding sites. The pseudosecond- order equation is

$t / q=1 / k_{2, \mathrm{ads}} q_{\mathrm{e}}^{2}+t / q_{\mathrm{e}}$

where $q_{\mathrm{e}}$ is the biosorption capacity at equilibrium $(\mathrm{mg} / \mathrm{g})$, $q$ the biosorption capacity at time $t(\mathrm{~min}), k_{1, \text { ads }}$ the firstorder reaction rate of adsorption (per min), $k_{2, \text { ads }}$ the pseudo-second-order rate constant of adsorption (mg/ $\mathrm{g}$ min). Application of different kinetic models to uranium biosorption suggested that uranium biosorption by ECDS followed the pseudo-second-order model rather than pseudo-first-order kinetic model (Table 2). The value of $q_{\mathrm{e}}$ obtained from pseudo-second-order model was in close agreement with that of the experimental value while the value obtained from pseudo-first-order model was quite small (Table 2). The results suggested that the kinetic data followed the pseudo-second-order kinetics in case of U(VI) biosorption on ECDS biomass.

\section{Effect of temperature}

Temperature is found to be a critical parameter in the removal of metal ions, but this is only for energy-dependent mechanisms. Many biosorption processes are affected to a limited extent under a certain range of temperature. The effect of temperature variation on the biosorption of U(VI) ions on ECDS from aqueous solution was investigated in the temperature range of $30-50{ }^{\circ} \mathrm{C}$. As seen in Fig. 6, the biosorption capacity of ECDS and $K_{\mathrm{d}}$ decreased with an increase in the temperature indicating that biosorption of $\mathrm{U}(\mathrm{VI})$ on ECDS was exothermic in nature. Maximum biosorption capacity $(57.80 \mathrm{mg} / \mathrm{g})$ and $K_{\mathrm{d}}$ were observed at $30{ }^{\circ} \mathrm{C}$ which decreased to $46.0 \mathrm{mg} / \mathrm{g}$ at $50{ }^{\circ} \mathrm{C}$. The decrease in biosorption capacity and $K_{\mathrm{d}}$ with increasing temperature might be due to the decreased surface activity. According to adsorption theory, adsorption decreases with increase in temperature and molecules adsorbed earlier on a surface tend to desorb from the

Table 1 Comparison between Langmuir and Freundlich isotherm parameters for U(VI) adsorption on ECDS

\begin{tabular}{|c|c|c|c|c|c|c|c|}
\hline \multirow[t]{2}{*}{ Metal } & \multicolumn{3}{|c|}{ Langmuir isotherm parameters } & \multirow{2}{*}{$\begin{array}{l}\text { Experimental value } \\
q_{\max }(\mathrm{mg} / \mathrm{g})\end{array}$} & \multicolumn{3}{|c|}{ Freundlich isotherm parameters } \\
\hline & $q_{\max }(\mathrm{mg} / \mathrm{g})$ & $K_{\mathrm{L}}(1 / \mathrm{mg})$ & $R^{2}$ & & $q_{\max }(\mathrm{mg} / \mathrm{g})$ & $k(\mathrm{mg} / \mathrm{g})$ & $R^{2}$ \\
\hline $\mathrm{U}(\mathrm{VI})$ & 10.13 & 0.002 & 0.581 & 57.75 & 54.49 & 0.508 & 0.946 \\
\hline
\end{tabular}


Table 2 Comparison between kinetic models for U(VI) adsorption on ECDS

\begin{tabular}{|c|c|c|c|c|c|c|c|}
\hline \multirow[t]{2}{*}{ Metal } & \multicolumn{3}{|c|}{ Pseudo-first-order kinetic model } & \multirow{2}{*}{$\begin{array}{l}\text { Experimental value } \\
q_{\mathrm{e}}(\mathrm{mg} / \mathrm{g})\end{array}$} & \multicolumn{3}{|c|}{ Pseudo-second-order kinetic model } \\
\hline & $q_{\mathrm{e}}(\mathrm{mg} / \mathrm{g})$ & $k_{1, \text { ads }}(\mathrm{mg} / \mathrm{g})$ & $R^{2}$ & & $q_{\mathrm{e}}(\mathrm{mg} / \mathrm{g})$ & $k_{2, \text { ads }}(\mathrm{mg} / \mathrm{g})$ & $R^{2}$ \\
\hline $\mathrm{U}(\mathrm{VI})$ & 0.435 & -0.06 & 0.983 & 57.75 & 58.8 & $2,769.92$ & 0.999 \\
\hline
\end{tabular}

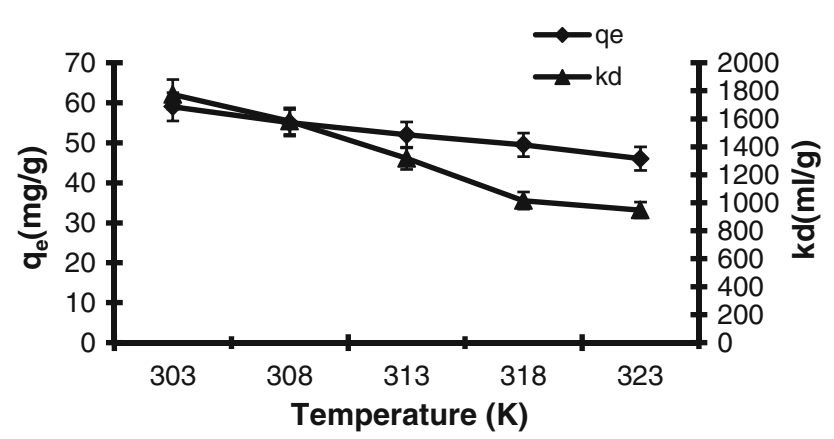

Fig. 6 Effect of temperature on the removal of U(VI) by ECDS (dose $0.5 \mathrm{~g} / 100 \mathrm{~mL}$; size $0.255 \mathrm{~mm}$; time $60 \mathrm{~min}$; $\mathrm{pH} 4$; concentration $100 \mathrm{mg} / \mathrm{L}$ )

surface at elevated temperatures (Jnr and Spiff 2005; Bhatti et al. 2010). As the process of biosorption is exothermic in nature, so by increasing the temperature rate of biosorption should decrease. The results are in accordance with biosorption theory. Bhat et al. (2008) investigated the biosorption of U(VI) from aqueous medium onto red alga and found no significant change in the biosorption capacity within the temperature range studied $\left(15-55^{\circ} \mathrm{C}\right)$.

The values of thermodynamic parameters for biosorption of $\mathrm{U}(\mathrm{VI})$ on ECDS are given in Table 3. The value of enthalpy of biosorption $\left(\Delta \mathrm{H}^{0}\right)$ is $-35.75 \mathrm{~kJ} / \mathrm{mol}$ indicating exothermic nature. The negative value of $\Delta \mathrm{G}^{0}$ indicated that the adsorption of $\mathrm{U}(\mathrm{VI})$ ion on ECDS is spontaneous at $30{ }^{\circ} \mathrm{C}$. However, with increase in temperature, the adsorption decreases due to increase in free energy. Therefore, high temperature is not favorable for $\mathrm{U}(\mathrm{VI})$ ion removal by ECDS. The value of $\Delta S^{0}$ suggests the decreased randomness at the solid-solution interface during biosorption of $\mathrm{U}(\mathrm{VI})$ on ECDS. Contrary to our findings, Donat and Ayata (2005) found that biosorption of $\mathrm{U}(\mathrm{VI})$ on to Ulva sp.-Na bentonite composite adsorbent

Table 3 Thermodynamic parameters for the removal of U(VI) on ECDS at different temperatures

\begin{tabular}{cclll}
\hline$T(\mathrm{~K})$ & $\Delta \mathrm{G}^{0}(\mathrm{~kJ} / \mathrm{mol})$ & $\Delta \mathrm{H}^{0}(\mathrm{~kJ} / \mathrm{mol})$ & $\Delta \mathrm{S}^{0}(\mathrm{~kJ} / \mathrm{mol} \mathrm{K})$ & $R^{2}$ \\
\hline 303 & -1.76 & -35.75 & 0.112 & 0.93 \\
308 & -1.61 & & & \\
313 & -0.92 & & & \\
318 & -0.13 & & & \\
323 & 7.2 & & & \\
\hline
\end{tabular}

was endothermic in nature and value of $\Delta G^{0}$ decreased with an increase in the temperature.

Effect of pretreatments

Metal ion affinities to the biomass can be modified by physical and/or chemical pretreatment of the biomass with alkali, acids, salts and organic solvents, which may increase or decrease the amount of the metal ions biosorbed. The physical treatments include simple heating, boiling or autoclaving. These treatments are easy and low costs, but sometimes no chemical modification in the structure of biomass is possible. The chemical treatments usually result in the modification in the functional moieties of the biomass thus altering its biosorption capacity. However, the major limitations include high cost and environmental problems. The results indicated that physical modification of biomass did not affect the biosorption capacity significantly. Chemical treatment with acids, alkali, EDTA, ammonium sulfate and glutaradehyde decreased the biosorption capacity of ECDS as compared to native biomass. The decrease in biosorption capacity of ECDS might be due to the damaging of binding sites of biomass on protonation of biomass with acids, destruction of autolytic enzymes responsible for putrefaction of biomass by alkali and masking of active sites by glutaradehyde (Zubair et al. 2008; Boota et al. 2009; Bhatti et al. 2010). Ammonium sulfate is a salting agent it can cause precipitation, which decreased the sorption capacity of biomass.

Chemical treatments with benzene, acetone, ethanol, methanol, ammonium chloride and PEI enhanced the biosorption capacity significantly as compared to native ECDS. A biosorption capacity of 83.25 and $59.5 \mathrm{mg} / \mathrm{g}$ was observed benzene and PEI treatment respectively. Removal of surface impurities, rupture of cell membrane and exposure of available binding sites for metal ions' adsorption after pretreatment might be responsible for the increase in adsorption capacity (Bhatti et al. 2009). PEI is a well-known chelating agent. Treatment of biomass with organic solvents generally enhanced the removal efficiency of biomass. Extraction with organic solvents removes the proteins and lipid fractions from the biomass surface (Ashkenazy et al. 1997). Thus, this treatment might expose more metal binding sites and improved the biosorptive property of the biomass. 


\section{Desorption and recovery studies}

The use of biosorbent in the wastewaters treatment depends not only on the biosorption capacity, but also on how well the biomass can be regenerated and used again. Although biosorption is a very useful process for the purification of wastewater polluted with heavy metal ions, the saturated adsorbent which contains U(VI) is not safe for disposal due to its radioactive nature. Therefore, it is important to devise a method for the regeneration and reuse of biosorbent so as to protect the environment from its harmful effects. Desorption of the biosorbed U(VI) ions from ECDS was studied in a batch mode using different eluents like $\mathrm{HNO}_{3}$, $\mathrm{H}_{2} \mathrm{SO}_{4}, \mathrm{CH}_{3} \mathrm{COOH}, \mathrm{HCl}, \mathrm{NaOH},\left(\mathrm{NH}_{4}\right)_{2} \mathrm{SO}_{4}, \mathrm{NH}_{4} \mathrm{Cl}$ and EDTA $(0.1 \mathrm{~N})$ solution. The results showed that $\mathrm{H}_{2} \mathrm{SO}_{4}$ solution was found to be the best eluting agent for the elution of uranium. It is clear from the results that acids are the good desorbing reagents. This may be due to the protonation of biomass under acidic conditions that make possible desorption of positively charged metal ions from the adsorbent surface.

The reusability of biosorbent was tested in five consecutive sorption-desorption cycles. For this cyclic study, biomass at concentration of $0.5 \mathrm{~g} / 0.1 \mathrm{~L}$ of uranium solution was used and $0.1 \mathrm{M} \mathrm{H}_{2} \mathrm{SO}_{4}$ was used as an eluent for desorption experiments. Both biosorption capacity and elution efficiency were measured after equilibrium time. In order to interpret the total efficiency of biosorbent, the data were proceeded to calculate the $\%$ desorption/elution and $\%$ decrease in dry weight of biosorbent/\% weight loss for each cycle. For first cycle, the values of $\%$ elution and $\%$ wt loss were 96 and 8, and decreased to 94 and 6.4, respectively. The results indicated that on increasing number of cycles \%wt loss increases with decrease in $\%$ elution and for five consecutive sorption-desorption cycles maximum loss is less than $10 \%$ for both parameters of efficiency. It can be concluded that on increasing the number of cycles, total efficiency of biosorbent in terms of $\%$ wt loss and $\%$ elution decreases. This decrease suggested that five consecutive biosorption-desorption cycles are enough for reusability.

\section{Infrared and EDAX analyses}

The changes in the functional groups and surface properties before and after adsorption of U(VI) on ECDS biomass were recorded as FT-IR spectrum. In general, the FT-IR spectra of plant biomasses have intense peaks in the range of 3,600-3,200/cm (Asgher and Bhatti 2010). In case of native biomass, a sharp peak at a frequency level of 3,600/ $\mathrm{cm}$ and two absorption bands one near $3,500 / \mathrm{cm}$ and one $3,400 / \mathrm{cm}$ may be arising due to non-associated $\mathrm{O}-\mathrm{H}$ stretching vibration and the antisymmetric and symmetric stretching vibrations of the two $\mathrm{N}-\mathrm{H}$ bonds, respectively. However, in case of uranium-loaded biomass a broad band near 3,600/cm may be assigned to the hydrogen bonded $\mathrm{O}-$ $\mathrm{H}$ and N-H groups (Singh et al. 2009). In case of uraniumloaded ECDS, a broad band near $3,600 / \mathrm{cm}$ may be assigned to the $\mathrm{H}$-bonded $-\mathrm{OH}$ and $-\mathrm{NH}$ groups. The appearance of a strong band just below 3,000/cm may be due to antisymmetric stretching of $\mathrm{C}-\mathrm{H}$ bond. The presence of sharp peak near $1,700 / \mathrm{cm}$ denotes the presence of $\mathrm{C}=\mathrm{O}$ stretching
Fig. 7 EDX-spectrum of a native and $\mathbf{b}$ uranium-loaded ECDS

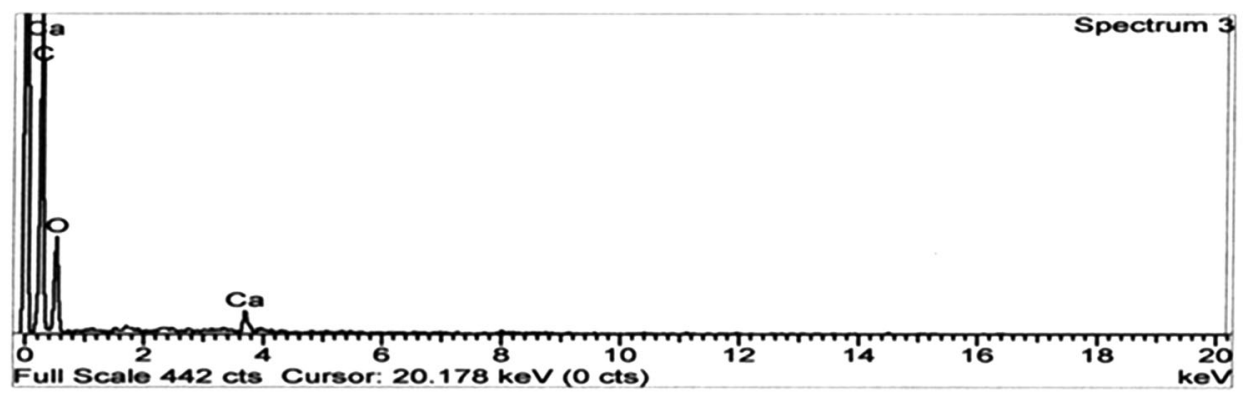

(a)

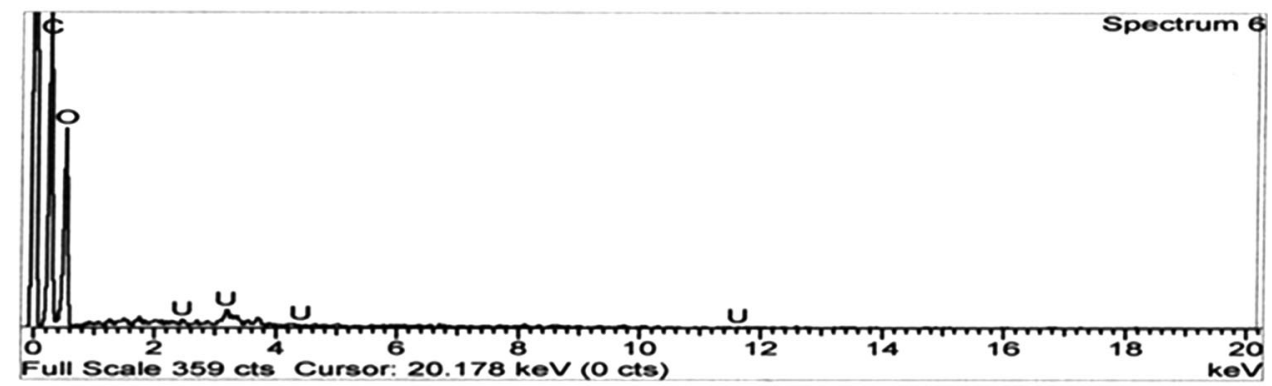

(b) 
while peak near $1,600 / \mathrm{cm}$ may be attributed to $\mathrm{C}=\mathrm{O}$ or $\mathrm{C}=\mathrm{N}$ stretching of carboxylic or imines. The band near $1,000 / \mathrm{cm}$ may be assigned to stretching vibration of $\mathrm{C}=\mathrm{O}$ group in the bonding. The IR spectral analysis before and after uranium loading indicated that the key components and structure remained integral; however, there is a substantial decrease in the intensity at $1,700-1,500 / \mathrm{cm}$ which is due to $-\mathrm{NH}$ bending and $3,600-3,400 / \mathrm{cm}$ due to $-\mathrm{OH}$ and $-\mathrm{NH}$ groups (Wang et al. 2010). The decrease in absorption intensity in these regions after adsorption of uranium indicated that hydroxyl, carboxyl and -NH group are involved in uranium binding. However, the $-\mathrm{NH}$ group plays a critical role in uranium $\left(\mathrm{UO}_{2}\right)^{2+}$ binding to ECDS biomass.

In order to know the chemical and elemental information about uranium adsorption and desorption different samples (native and uranium treated) of ECDS were subjected to X-ray energy dispersion (EDAX) analysis and results are shown in Fig. 7a, b. The EDAX spectrum of the ECDS before adsorption exhibits distinct calcium, oxygen and carbon peaks, indicating the presence of substantial amounts of these elements in the adsorbent. After uranium adsorption, all peaks of other metal ions diminished and spectra showed distinctive signal for uranium ions only.

\section{Conclusion}

In this study, Eucalyptus distillation sludge biomass was exploited for the removal of U(VI) from aqueous solutions. Maximum biosorption capacity $(57.75 \mathrm{mg} / \mathrm{g})$ of ECDS was observed with $\mathrm{pH} 4.0$, particle size $0.255 \mathrm{~mm}$, biosorbent dose $0.5 \mathrm{~g} / 100 \mathrm{~mL}$ and initial $\mathrm{U}(\mathrm{VI})$ concentration of $100 \mathrm{mg} / \mathrm{L}$. The biosorption of U(VI) on ECDS biomass was exothermic in nature. Pretreatments of ECDS with different reagents affected its biosorption capacity. A significant increase (34\%) in biosorption capacity of ECDS (83.25 mg/ g) was observed with benzene treatment. The Freundlich biosorption model could be used to describe this biosorption process, suggesting that this process is complicated multistep form. FT-IR studies showed the involvement of carbonyl, carboxyl and amide groups in the biosorption process. The results of this study showed that ECDS could be successfully used to remove U(VI) from aqueous effluents.

Acknowledgments The authors are thankful to Central Resource Laboratory, University of Peshawar for providing facilities for technical analyses.

\section{References}

Aksu Z (2002) Equilibrium and kinetic modeling of cadmium(II) by C. vulgaris in a batch system: effect of temperature. Sep Purif Technol 21:285-294
Asgher M, Bhatti HN (2010) Mechanistic and kinetic evaluation of biosorption of reactive azo dyes by free, immobilized and chemically treated Citrus sinensis waste biomass. Ecol Eng 36:1660-1665

Ashkenazy R, Gottlieb L, Yannai S (1997) Characterization of acetone washed yeast biomass functional groups involved in $\mathrm{Pb}^{2+}$ biosorption. Biotechnol Bioeng 5:1-10

Bai SR, Abraham TE (2003) Studies of Cr(VI) adsorption-desorption using immobilized fungal biomass. Bioresour Technol 87:17-26

Bhainsa KC, D'Souza SF (2001) Uranium (VI) biosorption by dried roots of Eichhornia crassipes (water hyacinth). J Environ Sci Health A 36:1621-1631

Bhat SV, Melo JS, Chaugule BB, D'Souza SF (2008) Biosorption characteristics of uranium (VI) from aqueous medium onto Catenella repens, a red alga. J Hazard Mater 158:628-635

Bhatti TM, Mateen M, Amin M, Kauser AM, Khalid AM (1991) Spectrophotometric determination of uranium (VI) in bacterial leach liquors using arsenazo-III. J Chem Technol Biotechnol 52:331-341

Bhatti HN, Khalid R, Hanif MA (2009) Dynamic biosorption of $\mathrm{Zn}(\mathrm{II})$ and $\mathrm{Cu}(\mathrm{II})$ using pretreated Rosa gruss an teplitz (red rose) distillation sludge. Chem Eng J 148:434-443

Bhatti HN, Bajwa II, Hanif MA, Bukhari IH (2010) Removal of lead and cobalt using lignocellulosic fiber derived from Citrus reticulata waste biomass. Korean J Chem Eng 27:218-227

Boddu VM, Abburi K, Talbott JL, Smith ED (2003) Removal of $\mathrm{Cr}(\mathrm{VI})$ from wastewater using a new composite chitosan biosorbent. Environ Sci Technol 37:4449-4456

Boota R, Bhatti HN, Hanif MA (2009) Removal of Cu(II) and Zn(II) using lignocellulosic fiber derived from Citrus reticulate (Kinnow) waste biomass. Sep Sci Technol 44:4000-4022

Donat R, Ayata S (2005) Adsorption and thermodynamic behavior of uranium(VI) on Ulva sp.-Na bentonite composite adsorbent. J Radioanal Nucl Chem 265:107-114

Dursun AY (2006) A comparative study on determination of the equilibrium, kinetic and thermodynamic parameters of biosorption of copper(II) and lead(II) ions onto pretreated Aspergillus niger. Biochem Eng J 28:187-195

Freundlich H (1906) Adsorption in solution. Phys Chem Soc 40:1361-1368

Gok C, Aytas S (2009) Biosorption of uranium (VI) from aqueous using calcium alginate beads. J Hazard Mater 168:504-508

Jnr MH, Spiff AI (2005) Effect of temperature on the sorption of $\mathrm{Pb}^{2+}$ and $\mathrm{Cd}^{2+}$ from aqueous solution by Caladium bicolor (wild cocoyam) biomass. Elect J Biotechnol 8:162-169

Jovanovic SV, Pan P, Wong L (2012) Bioaccessibility of uranium in soil samples from Port Hope, Ontario, Canada. Environ Sci Technol 46:9012-9018

Kalin M, Wheeler WN, Meinrath G (2005) The removal of uranium from mining waste water using algal/microbial biomasses. J Environ Radioact 78:151-177

Kratochvil D, Volesky B (1998) Advances in the biosorption of heavy metals. Trends Biotechnol 16:291-300

Lagergren (1898) Zur theorie der sogenannten adsorption geloster stoffe, Kungliga Svenska Vetenkapsakademiens. Handlinger Band 24:1-39

Langmuir I (1918) The adsorption of gases on plane surfaces of glass, mica, and platinum. J Am Chem Soc 40:1361-1368

Li X, Wu J, Liao J, Zhang D, Yang J, Feng Y, Zeng J, Wen W, Yang Y, Tang J, Liu N (2012) Adsorption and desorption of uranium (VI) in aerated zone soil. J Environ Radioact 115:143-150

Ozer A, Ozer D (2003) Comparative study of the biosorption of $\mathrm{Pb}$ (II), $\mathrm{Ni}$ (II) and $\mathrm{Cr}(\mathrm{VI})$ ions onto $S$. cervesiae determination of biosorption heats. J Hazard Mater 100:219-229

Saifuddin N, Dinara S (2012) Immobilization of Saccharomyces cerevisiae onto cross-linked Chitosan coated with magnetic 
nanoparticles for adsorption of uranium (VI) ions. Adv Nat Appl Sci 6:249-267

Saleem N, Bhatti HN (2011) Adsorptive removal and recovery of $\mathrm{U}(\mathrm{VI})$ by citrus waste biomass. Bioresources 6:2522-2538

Sar P, D' Souza SF (2002) Biosorption of thorium (IV) by a Pseudomonas biomass. Biotechnol Lett 24:239-243

Singh V, Sharma AK, Tripathi DN, Shanghi R (2009) Poly (methylmethacrylate) grafted chitosan: an efficient adsorbent for anionic azo dyes. J Hazard Mater 161:955-966

Tuzen M, Saygi KO, Usta C, Soylak M (2008) Pseudomonas aeruginosa immobilized multiwalled carbon nanotubes as biosorbent for heavy metal ions. Bioresour Technol 99:1563-1570

Wang J, Hu X, Liu Y, Xie S, Bao Z (2010) Biosorption of U(VI) by immobilized Aspergillus fumigatus beads. J Environ Radioact 101:504-508

Wazne M, Meng X, Korfiatis GP, Christodoulatos C (2006) Christodoulatos carbonate effects on hexavalent uranium removal from water by nanocrystalline titanium dioxide. J Hazard Mater 136:47-52

Xie S, Yang J, Chen C, Zhang X, Wang Q, Zhang C (2008) Study on biosorption kinetics and thermodynamics of uranium by Citrobacter freundii. J Environ Radioact 99:126-133

Yang J, Volesky B (1999) Biosorption of uranium on Sargassum biomass. Water Res 33:3357-3363

Zou W, Zhao I (2012) Removal of uranium(VI) from aqueous solution using citric acid modified pine sawdust: Batch and column studies. J Radioanal Nucl Chem 291:585-595

Zubair A, Bhatti HN, Hanif MA, Shafqat F (2008) Kinetic and Equilibrium modeling for $\mathrm{Cr}(\mathrm{III})$ and $\mathrm{Cr}(\mathrm{VI})$ removal from aqueous solutions by Citrus reticulate waste biomass. Water Air Soil Pollut 191:305-318 